\title{
Pengembangan sistem informasi administrasi keuangan (SIAKU) BUMDes Banyu Aji berbasis website di Desa Slumbung Kecamatan Gandusari Kabupaten Blitar
}

\author{
Tata Mustika Dewi, Agung Winarno* \\ Universitas Negeri Malang, Jl. Semarang No. 5 Malang, Jawa Timur, Indonesia \\ *Penulis korespondensi, Surel: agung.winarno.fe@um.ac.id
}

Paper received: 3-3-2021; revised: 24-3-2021; accepted: 28-3-2021

\begin{abstract}
Abstrak
Perkembangan teknologi dan informasi yang pesat mengakibatkan banyak perubahan pada kehidupan manusia. Perkembangan tersebut dapat dimanfaatkan dalam menyelesaikan pekerjaan pengolahan data pelanggan dan data transaksi keuangan termasuk di Badan Usaha Milik Desa (BUMDes) secara efektif dan efisien. Oleh karena itu, penelitian ini bertujuan untuk menghasilkan produk sistem informasi adminitrasi keuangan berbasis website guna meningkatkan keefektifan pelayanan dalam pembayaran biaya tagihan air bersih di BUMDes. Produk sistem informasi adminitrasi keuangan yang dikembangkan terdapat 4 menu utama, 7 submenu dan fitur yang mempermudah pengguna dalam pengoperasianya. Sistem dikembangkan sesuai dengan kebutuhan serta cara mengaksesnya yang mudah sehingga dapat membantu pengguna perangkat BUMDes dalam meningkatkan kinerjanya. Penelitian dan pengembangan ini menggunakan model Reseacrh and Development Borg and Gall yang telah dimodifikasi. Teknik analisa data menggunakan rata-rata yang dikategorikan menggunakan jenjang kevalidan dan tingkatan. Hasil penelitian dan pengembangan ini adalah Sistem Informasi Adminitrasi Keuangan berbasis website yang bernama SIAKU yang telah dinyatakan sangat layak dan efektif diterapkan di BUMDes oleh ahli media, ahli materi dan uji coba pengguna pada masyarakat dan perangkat BUMDes. Hal tersebut dibuktikan pada perolehan hasil persentase data kuantitatif pengisian angket yang masuk dalam kategori "sangat baik". Sehingga dapat disimpulkan bahwa SIAKU layak dan efektif digunakan sebagai media pengolahan data pelanggan dan data transaksi keuangan di BUMDes untuk meningkatkan kualitas pelayanan administrasi.
\end{abstract}

Kata kunci: administrasi keuangan; BUMDes; sistem informasi; penelitian dan pengembangan; website.

\section{Pendahuluan}

Perubahan jaman telah mendorong manusia untuk selalu berkembang, hal tersebut dapat diwujudkan dengan melakukan transisi pada teknologi komputer yang dijadikan sebagai alat bantu kerja terutama dalam bidang sistem informasi dan administrasi keuangan (Almaiah et al., 2020). Dengan menggunakan sistem teknologi tersebut mampu memberikan kemudahan dalam menyelesaikan pekerjaan pengolahan data secara efektif dan efisien (Alshira' $\mathrm{H}, 2020$ ). Sistem informasi sendiri merupakan sebuah sistem yang mempertemukan beberapa kebutuhan seperti transaksi harian guna mendukung kegiatan operasional yang bersifat manajerial (Wildaningsih \& Yulianeu, 2018). Sedangkan adminitrasi keuangan merupakan suatu proses pengelolaan seluruh kegiatan yang berkaitan dengan laporan keuangan guna mencapai tujuan bersama (Nugraha \& Setiawan, 2017). Kemajuan sistem ini dapat diterapkan di Badan Usaha Milik Desa (BUMDes) dalam pengolahan data pelanggan dan transaksi keuangan. Badan Usaha Milik Desa (BUMDes) diatur dalam Pasal 1 ayat (6) Peraturan Dalam Negeri Nomor 39 Tahun 2010, yang menyatakan bahwa BUMDes merupakan suatu usaha desa yang didirikan oleh pemerintah setempat yang mana kepemilikan modal dan pengelolaanya

This work is licensed under a Creative Commons Attribution-ShareAlike 4.0 International License. 
dilakukan oleh sebagaian masyarakat di desa. Pengembangan sistem teknologi kini telah menjadi trend inovatif yang bersifat modern khusunya pada sistem berbasis website karena dapat meningkatkan kinerja adminitrasi dan manajemen layanan masyarakat.

Pemanfaatan sistem berbasis website diharapkan dapat memberikan kemudahan kepada pengguna dalam mengakses dan mendistribusikan informasi secara online sehingga tidak terhambat oleh waktu dan biaya (Lee et al., 2020; Arifin \& Ivo Jayanti, 2019; Yusvanli \& Alimuddin, 2019). Sistem yang dikembangkan dalam penelitian ini yaitu Sistem Informasi Adminitrasi Keuangan berbasis Website. Sistem tersebut dalam bentuk web yang dapat diakses melalui link dimana terdapat beberapa menu dan fitur yang mendukung pengolahan data (Maggay, 2019; Nuanmeesri, 2020).

Beberapa penelitian sebelumnya yang juga membahas tentang tema ini adalah penelitian (Al amin \& Susatyono, 2018; Bratakusuma et al., 2019; Cheng, 2012; Gomber et al., 2018; Hasan et al., 2013; Triani \& Handayani, 2018; Andrianof, 2018; Murtopo \& Angesti, 2017; Nofyat et al., 2018; Rizan et al., 2018). Berdasarkan penelitian-penelitian tersebut dapat disimpulkan bahwa sistem informasi adminitrasi keuangan dapat digunakan secara online untuk menunjang pengoperasian sistem yang lebih efektif dan efisien.

Akan tetapi, berdasarkan hasil wawancara bersama ketua Pengelola Air Bersih Banyu Aji di Desa Slumbung Kecamatan Gandusari Kabupaten Blitar memperoleh informasi bahwa pengolahan data pelanggan dan transaksi keuangan disana masih dilakukan secara konvensional yaitu pencatatan menggunakan buku, Microsoft Excel, dan penghitungan tarif biaya menggunakan kalkulator secara manual. Hal tersebut berpotensi menimbulkan kendala misalnya hilangnya data, kesalahan dalam penghitungan tarif pembayaran, serta membutuhkan waktu yang lama dalam pencarian data. Dari permasalahan tersebut peneliti berinovasi membuat sebuah sistem berbasis website untuk menunjang kegiatan pengolahan data agar lebih efektif. Peneliti meembuat sistem informasi administrasi keuangan yang dapat diakses secara online melalui komputer dan handphone yang terkoneksi dengan jaringan internet. Sistem ini berisikan menu data pengguna, menu transaksi, menu rekap, menu surat, dan submenu serta beberapa fitur pendukung. 


\section{Metode}

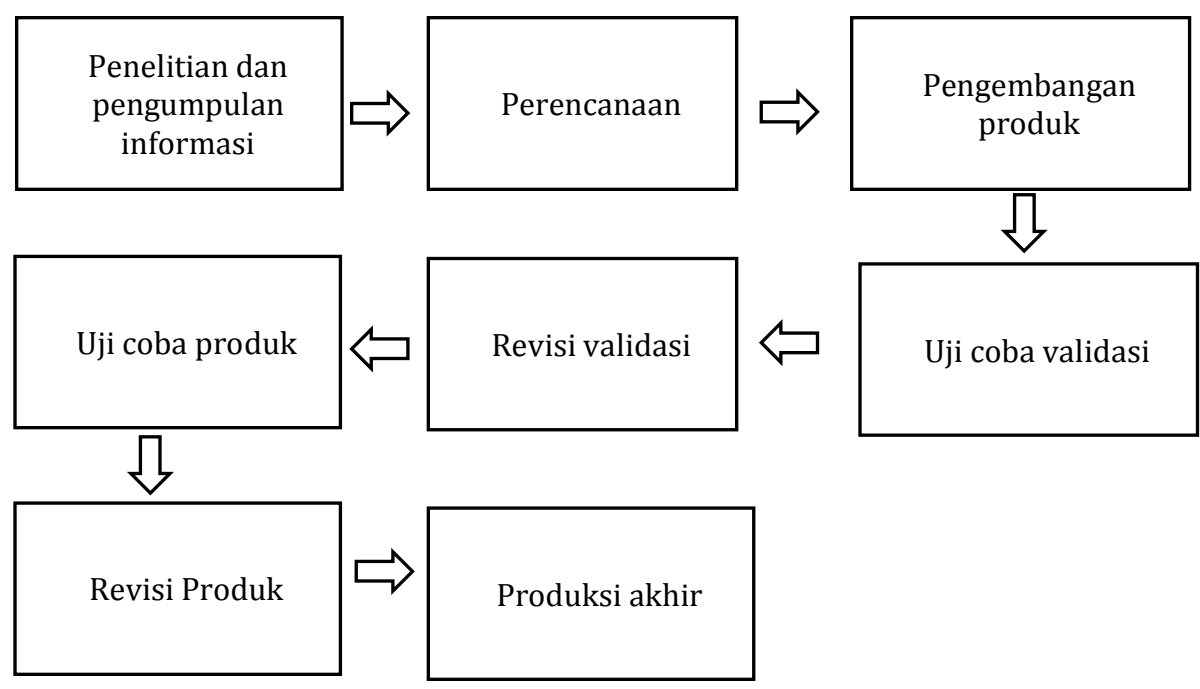

Gambar 1. Langkah-Langkah Penelitian

Penelitian ini menggunakan model Research and Development Borg and Gall yang telah dimodifikasi menjadi delapan langkah untuk mempersingkat waktu dan keadaan lapangan (Z. Arifin, 2011; Limpeeticharoenchot et al., 2020; Wongkhamdi et al., 2020). Selain itu, peneliti juga merasa bahwa tujuan penelitian yaitu untuk menghasilkan produk, mengetahui kelayakan produk, dan menguji keefektifan produk dalam meningkatkan kualitas pelayanan adminitrasi keuangan.

Langkah pertama, peneliti melakukan penelitian dan pengumpulan informasi terkait permasalahan pengolahan data pelanggan dan transaksi keuangan yang terjadi di BUMDes Banyu Aji. Langkah kedua, peneliti melakukan perencanaan terkait sistem yang akan dikembangkan. Langkah ketiga, peneliti mengembangkan format produk awal sistem informasi adminitrasi keuangan yang akan dikembangkan dan dapat menjadi solusi atas permasalahan yang ditemukan pada langkah potensi dan masalah serta pengumpulan informasi serta mulai membuat sistem sesuai rancangan yang telah ditentukan pada langkah sebelumnya. Langkah keempat, sistem yang dihasilkan peneliti diuji kelayakan oleh validator, yaitu satu ahli media dan satu ahli materi. Langkah kelima, produk yang telah divalidasi direvisi berdasarkan masukan dan saran baik secara lisan maupun tulisan yang tertera pada lembar angket penilaian ahli media dan ahli materi. Langkah keenam, produk yang telah direvisi diujicobakan kepada perangkat kantor dan masyarakat pelanggan Banyu Aji untuk megetahui tingkat keefektifaanya. Langkah ketujuh, produk yang telah diuji cobakan pada perangkat desa dan masyarakat pelanggan Banyu Aji direvisi sesuai masukan-masukan baik secara lisan ataupun tulisan yang tertera pada lembar hasil angket uji coba pengguna. Langkah kedelapan, produk yang telah melewati revisi produk dari uji coba pengguna menjadi produk akhir dalam penelitian ini.

Data yang dihasilkan dari penelitian ini meliputi data kualitatif dan kuatitatif dimana data kualitatif diperoleh dari komentar, saran, dan catatan oleh ahli media, ahli materi, dua perangkat kantor, dan pengguna. Sedangkan data kuantitatif diperoleh dari hasil pengisian angket oleh ahli media, ahli materi, dan pengguna. Teknik analisa data yang digunakan yaitu statistik deskriptif. Data hasil pengisian angket validasi ahli media dan ahli materi digunakan 
untuk mengetahui tingkat kelayakan dari sistem yang dikembangkan. Sedangkan data hasil pengisian angket pengguna digunakan untuk mengetahui keefektifan sistem yang di kembangkan.

\section{Hasil dan Pembahasan}

Produk yang dihasilkan dalam penelitian dan pengembangan ini adalah Sistem Informasi Adminitrasi Keuangan Berbasis Website di BUMDes Banyu Aji. Sistem Informasi Adminitrasi Keuangan (SIAKU) terdiri dari dua tampilan yang dapat diakses oleh masyarakat dan perangkat kantor (admin). Tampilan pertama di dalam menu dapat diakses oleh masyarakat untuk melakukan pendaftaran mandiri dapat dilihat pada Gambar 2 berikut ini:

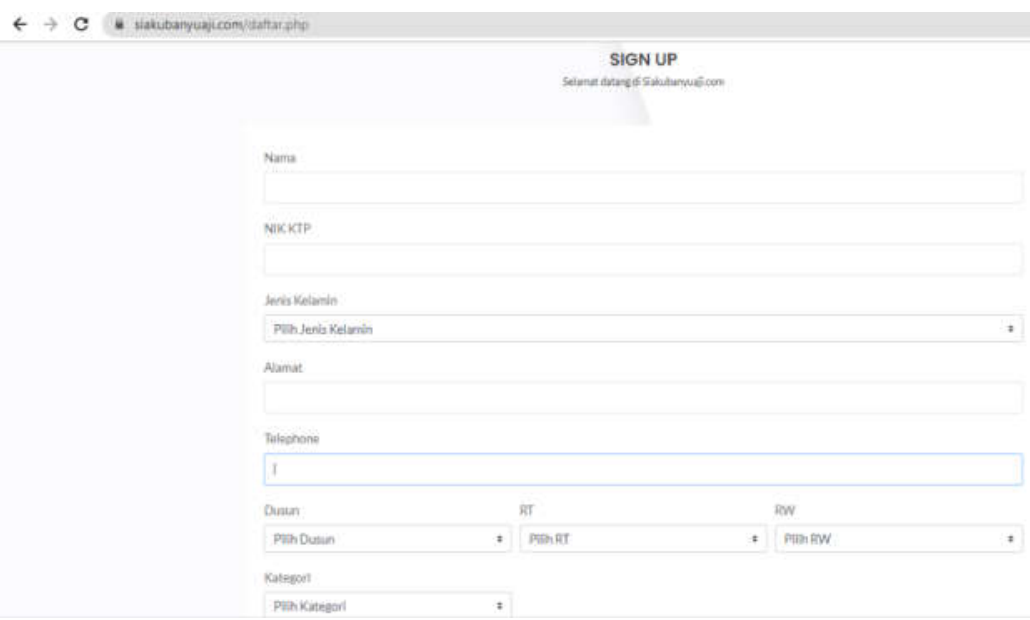

Gambar 2. Tampilan daftar pelanggan secara mandiri pada SIAKU

Selanjutnya masyarakat yang telah menjadi pelanggan Banyu Aji dapat mengecek tagihan perbulan dengan melakukan login terlebih dahulu yang dapat dilihat pada Gambar 3 berikut ini:

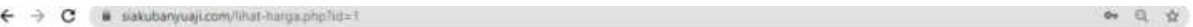

\section{Rp. 10000}

Toral meter 20

Gambar 3. Tampilan biaya tagihan perbulan pada SIAKU

Kemudian pada tampilan kedua hanya dapat diakses oleh perangkat kantor (Admin) yang terdiri beberapa menu dijelaskan melalui Gambar 4 berikut ini: 


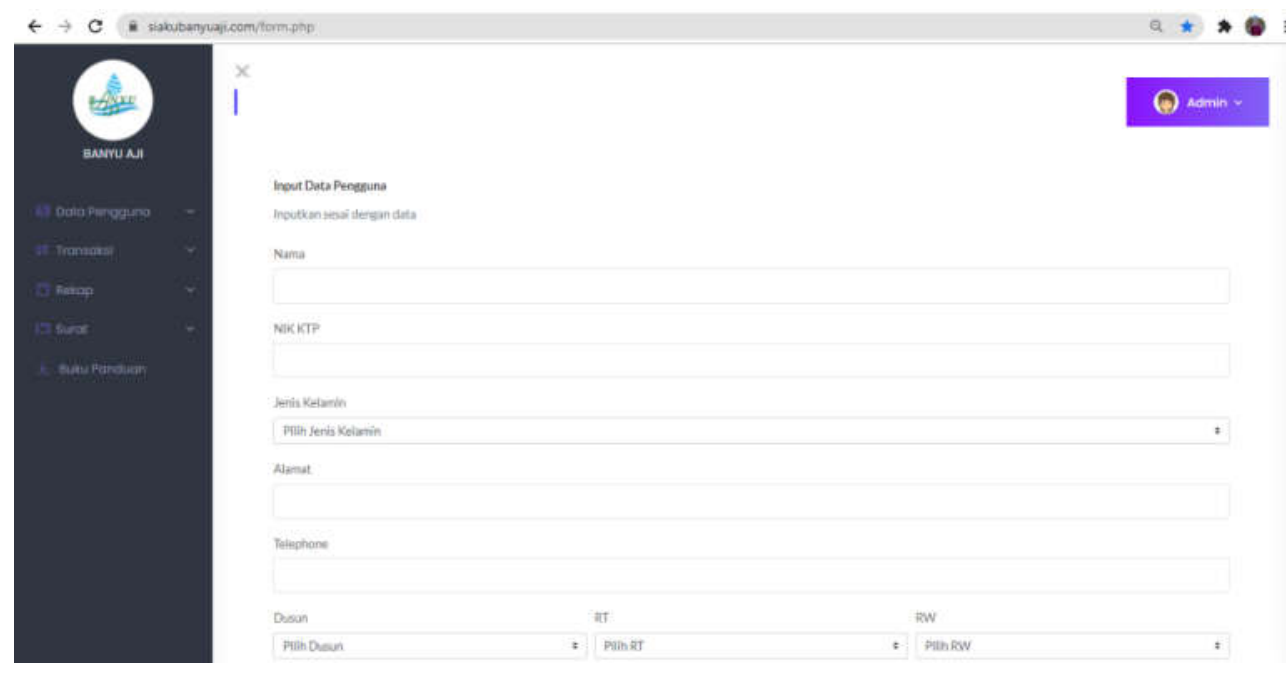

Gambar 4 Menu pada tampilan kedua SIAKU

Hasil validasi SIAKU oleh validator ahli media dan ahli materi secara kesuluruhan disajikan dalam Tabel 1 berikut ini:

Tabel 1. data hasil validasi keseluruhan

\begin{tabular}{clll}
\hline No & Validasi & Persentase & Kriteria Validitas \\
\hline Ahli Media & $94,6 \%$ & Sangat Layak \\
& Ahli Materi & $84 \%$ & Sangat Layak \\
Rata-rata & $88 \%$ & Sangat Layak \\
\hline \multicolumn{2}{l}{ Table used by permission CTata Mustika Dewi, 2021. Datahasilvalidasikeseluruhan }
\end{tabular}

Berdasarkan Tabel 1, diketahui rata-rata persentase validasi secara kesuluruhan sebesar 88\%, sehingga dapat disimpulkan bahwa sistem informasi Administrasi keuangan (SIAKU) berbasis website, dinyatakan "sangat layak"digunakan dalam pengolahan data pelanggan dan transaski keuangan di BUMDes Banyu Aji. Hal ini senada dengan penelitian sebelumnya, dimana hasil validasi ahli media dan ahli materi dijadikan dasar penentu apakah sistem yang dikembangkan layak atau tidak digunakan didalam kegiatan pengolahan data (Almuqsitu et al., 2019), (Adnyana et al., 2019).

Titik pengukuran berupa validalitas mengacu pada hasil pengukuran yang dilakukan untuk mengetahui seberapa banyak aspek dalam ranah kuantitatif pada instrument pengukuran yang dinyatakan dengan skor (Sugiyono, 2017). SIAKU menyajikan empat menu utama untuk admin dan dua menu untuk masyarakat serta serta beberapa fitur pendukung yang mempermudah pengguna dalam pengoperasianny. Sistem dibuat sesuai dengan kebutuhan BUMDes Banyu Aji, serta sistem dibuat semudah mungkin dalam mengakses yaitu dengan menginput link siakubanyuaji.com pada Google/Browser. Hal tersebut dapat mempercepat dalam pengolahan data, meningkatkan kinerja dan pelayan digital (Nugraha \& Setiawan, 2017), (Nofyat et al., 2018), (Andrianof, 2018).

Sedangkan uji coba keefektifan SIAKU dilakukan oleh pengguna yaitu perangkat kantor dan masyarakat pelangan Banyu Aji secara keseluruhan disajikan dalam Tabel 2 berikut ini: 
Tabel 2. data hasil uji coba pengguna

\begin{tabular}{llll}
\hline No & Subjek Uji Coba & Persentase & Kriteria Validitas \\
\hline & 2 Perangkat Kantor & $82,85 \%$ & Sangat Efektif \\
& 5 Masyarakat & $93,86 \%$ & Sangat Efektif \\
& Rata-rata & $87 \%$ & Sangat Efektif \\
\hline
\end{tabular}

Table used by permission (T) Tata Mustika Dewi, 2021. Datahasilujicobapenggunakeseluruhan

Pada Tabel 2 menunjukkan rata-rata persentase pengguna secara kesuluruhan sebesar 87\%, sehingga dapat disimpulkan bahwa sistem informasi Administrasi keuangan (SIAKU) berbasis website, dinyatakan "sangat efektif" diterapkan dalam pengolahan data pelanggan dan transaksi keuangan di BUMDes Banyu Aji. Hal ini senada dengan penelitian sebelumnya, dimana hasil ujicoba pengguna dijadikan dasar penentu apakah sistem yang dikembangkan efektif atau tidak diterapkan didalam kegiatan pengolahan data (Suriyani, 2020).

Titik pengukuran berupa validalitas mengacu pada hasil pengukuran yang dilakukan untuk mengetahui seberapa banyak aspek dalam ranah kuantitatif pada instrument pengukuran yang dinyatakan dengan skor (Sugiyono, 2017). SIAKU mendapatkan respon yang baik dari pengguna karena dianggap memudahkan proses pengguna dalam melakukan pendaftaran, info tagihan dan cek pembayaran, serta pencarian data pelanggan yang cepat (Aris et al., 2017).

\section{Simpulan}

Penelitian dan pengembangan ini menghasilkan sistem informasi administrasi keuangan berbasis website di BUMDes Banyu Aji untuk meningkatkan keefektifan pengolahan data dan pelayanan pelanggan. Sistem ini bernama SIAKU yang dapat diakses secara online melalui komputer dan handphone yang memiliki jaringan internet. Pengguna dapat menginputkan link siakubanyuaji.com pada google/browser.

Sistem pada penelitian ini telah dinyatakan "Sangat Layak" digunakan dalam pengolahan data pelanggan dan transaksi keuangan melalui validasi oleh ahli media dan ahli materi. Kemudian sistem ini dinyatakan "Sangat Efektif" diterapkan di BUMDes Banyu Aji melalui uji coba produk pada pengguna. SIAKU ini dapat berjalan dengan optimal apabila pengguna memiliki koneksi internet yang baik.

SIAKU hanya berfokus pada kegiatan pengolahan data pelanggan, data pembayaran tagihan, dan laporan rekapan jurnal rekening tiap bulan. Untuk rumus perhitungan biaya tagihan masih bersifat permanen sehingga diharapkan untuk peneliti selanjutnya mengembangkan sistem yang terdapat fitr setting.

\section{Daftar Rujukan}

Adnyana, P. B. I., Dharma, S. B. G. I., \& Arta, D. M. I. (2019). Penyediaan Air Bersih Perdesaan di Desa Bukian Gianyar Ida Bagus Putu Adnyana , I Gusti Bagus Sila Dharma, dan I Made Dwipa Arta Analysis of Factors Affecting the Performance of Clean Water Supply Management in Village Bukian Gianyar. 7(1), 123-131.

Al amin, K., \& Susatyono, J. D. (2018). Sistem Informasi Pencatatan dan Perhitungan Biaya Penggunaan Air Bersih Berbasis Andoid. Ilmiah Ekonomi Dan Bisnis, 11.

Almaiah, M. A., Al-Khasawneh, A., Althunibat, A., \& Khawatreh, S. (2020). Mobile Government Adoption Model Based on Combining GAM and UTAUT to Explain Factors According to Adoption of Mobile Government Services. International Journal of Interactive Mobile Technologies, 14(3), 199-225. https://doi.org/10.3991/ijim.v14i03.11264 
Almuqsitu, A. B., Tursina, T., \& S, A. S. (2019). Rancang Bangun Aplikasi Pelayanan Pelanggan PDAM Tirta Kapuas Berbasis Web. Jurnal Sistem Dan Teknologi Informasi (JUSTIN), 7(1), 13. https://doi.org/10.26418/justin.v7i1.27363

Alshira'H, M. H. (2020). The Effects of Usability and Accessibility for E-Government Services on the End-User Satisfaction. International Journal of Interactive Mobile Technologies, 14(13), 78-90. https://doi.org/10.3991/ijim.v14i13.14659

Andrianof, H. (2018). Pusat Informasi Pada Perusahaan Daerah Air Minum (PDAM) Kota Padang Berbasis Website. Majalah Ilmiah, 25(2), 189-206.

Arifin, M., \& Ivo Jayanti, N. (2019). Sistem Informasi Layanan Pelanggan Berbasis Web Di Pdam Kabupaten Grobogan. Jurnal SITECH: Sistem Informasi Dan Teknologi, 1(2), 171-180. https://doi.org/10.24176/sitech.v1i2.2657

Arifin, Z. (2011). Penelitian Pendidikan (A. Kamsyach (ed.); Pertama). PT Remaja Rosdakarya.

Aris, Laeliyah, Putra, M. I., Priskilawati, \& Sihabudina. (2017). Aplikasi Sistem Pelayanan Data Pelanggan Berbasis Web Pada PDAM Tirta Benteng Kota Tangerang. 79-84.

Bratakusuma, T., Kuswanto, E., \& Rifai, Z. (2019). Integrasi Pembayaran Pamsimas Desa Dermaji dengan PPOB Menggunakan Web Service. Journal of Innovation Information Technology and Application (JINITA), 1(01), 61-67. https://doi.org/10.35970/jinita.v1i01.95

Cheng, Y. (2012). Thoughts on Reconstruction of Financial Control System in Chinese Listed Companies in Perspective of Systems Theory. International Journal of Business Administration, 3(4), 67-71. https://doi.org/10.5430/ijba.v3n4p67

Gomber, P., Kauffman, R. J., Parker, C., \& Weber, B. W. (2018). On the Fintech Revolution: Interpreting the Forces of Innovation, Disruption, and Transformation in Financial Services. Journal of Management Information Systems, 35(1), 220-265. https://doi.org/10.1080/07421222.2018.1440766

Hasan, M. R., Ibrahimy, M. I., Motakabber, S. M. A., Ferdaus, M. M., Khan, M. N. H., \& Mostafa, M. G. (2013). Development of a web based financial application system. IOP Conference Series: Materials Science and Engineering, 53(1). https://doi.org/10.1088/1757-899X/53/1/012080

Lee, T., Lee, B. K., \& Lee-Geiller, S. (2020). The effects of information literacy on trust in government websites: Evidence from an online experiment. International Journal of Information Management, 52(February). https://doi.org/10.1016/j.ijinfomgt.2020.102098

Limpeeticharoenchot, S., Cooharojananone, N., Chavarnakul, T., Tuaycharoen, N., \& Atchariyachanvanich, K. (2020). Innovative Mobile Application for Measuring Big Data Maturity: Case of SMEs in Thailand. International Journal of Interactive Mobile Technologies, 14(18), 87-106. https://doi.org/10.3991/ijim.v14i18.16295

Maggay, J. G. (2019). Usability evaluation of SMS-based system: Basis for systems development. International Journal of Interactive Mobile Technologies, 13(9),113-125. https://doi.org/10.3991/ijim.v13i09.10918

Murtopo, A. A., \& Angesti, D. C. (2017). Sistem Informasi Pelayanan Tagihan Rekening dan Pengaduan Pelanggan Berbasis SMS Gateway di PDAM kota Tegal. Simetris, 8, 457-468.

Nofyat, Ibrahim, A., \& Ambarita, A. (2018). Sistem Informasi Pengaduan Pelanggan Air Berbasis Website Pada PDAM Kota Ternate. Indonesia Journal on Information System, 3(April), 10. http://ijiswiratama.org/index.php/home/article/view/37

Nuanmeesri, S. (2020). Mobile application development of managing elderly household accounts using speech recognition. International Journal of Interactive Mobile Technologies, 14(2), 84-100. https://doi.org/10.3991/ijim.v14i02.11651

Nugraha, S. A., \& Setiawan, R. (2017). Perancangan Sistem Informasi Pengolahan Administrasi Keuangan Sekolah Menengah Pertama Islam Terpadu Assalam Garut. Jurnal Algoritma, 13(2), 320-332. https://doi.org/10.33364/algoritma/v.13-2.320

Rizan, O., Hamidah, \& Pramana, D. (2018). Penerapan Metode FAST (Framework Aplication System Thinking) Untuk Peningkatan Pelayanan Air Bersih Kapal Sandar. Atmaluhur, 74(4), 55-61.

Sugiyono. (2017). Metode Penelitian Kuantitatif, Kualitatif, dan R\&D. Alfabeta.

Suriyani, I. (2020). Sistem Informasi Pembayaran Rekening Air Berbasis Web Pada Pamsimas Jorong Panyalai. Indonesian Journal of Technology, Informatics and Science (IJTIS), 1(2), 21-26. https://doi.org/10.24176/ijtis.v1i2.4833 
Jurnal Ekonomi, Bisnis dan Pendidikan, 1(3), 2021, 297-304

Triani, N. N. A., \& Handayani, S. (2018). Praktik Pengelolaan Keuangan Dana Desa. Jurnal Akuntansi Multiparadigma, 9(1), 136-155. https://doi.org/10.18202/jamal.2018.04.9009

Umar, Y., \& Yasin, A. (2019, December). PERANCANGAN SISTEM PENGAJUAN PEMASANGAN BARU PDAM. In SemanTECH (Seminar Nasional Teknologi, Sains dan Humaniora) (Vol. 1, No. 1, pp. 145-153).

Wildaningsih, W., \& Yulianeu, A. (2018). Sistem Informasi Pengolahan Data Anggota Unit Keagiatan Mahasiswa (UKM) Zaradika STMIK DCI Tasikmalaya. Jumantaka, 2(1), 181-190.

Wongkhamdi, T., Cooharojananone, N., \& Khlaisang, J. (2020). E-commerce competence assessment mobile application development for SMEs in Thailand. International Journal of Interactive Mobile Technologies, 14(11), 48-75. https://doi.org/10.3991/ijim.v14i11.11358

Yusvanli, U., \& Alimuddin, Y. (2019). Perancangan Sistem Pengajuan Pemasangan Baru PDAM Yusvanli Umar 1 , Alimuddin Yasin 2 1,2. ISBN, 2019(November), 145-153. 